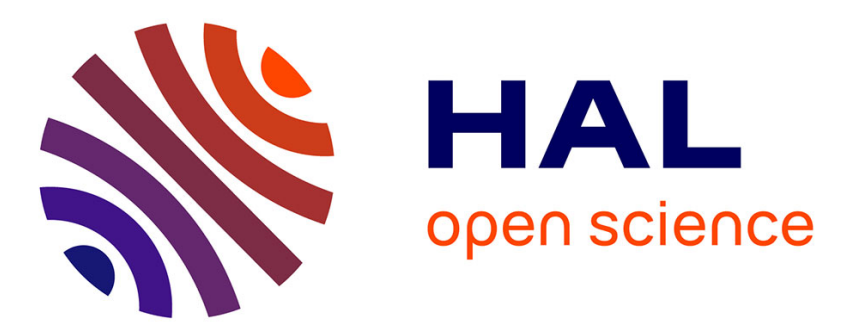

\title{
Crustal structure and gravity anomalies beneath the Rif, northern Morocco: implications for the current tectonics of the Alboran region
}

Carole Petit, Laetitia Le Pourhiet, Bruno Scalabrino, Michel Corsini, Mickael Bonnin, Adrien Romagny

\section{To cite this version:}

Carole Petit, Laetitia Le Pourhiet, Bruno Scalabrino, Michel Corsini, Mickael Bonnin, et al.. Crustal structure and gravity anomalies beneath the Rif, northern Morocco: implications for the current tectonics of the Alboran region. Geophysical Journal International, 2015, 202, pp.640 - 652 . $10.1093 /$ gji/ggv169 . hal-02546672

\section{HAL Id: hal-02546672 \\ https://hal.science/hal-02546672}

Submitted on 18 Apr 2020

HAL is a multi-disciplinary open access archive for the deposit and dissemination of scientific research documents, whether they are published or not. The documents may come from teaching and research institutions in France or abroad, or from public or private research centers.
L'archive ouverte pluridisciplinaire HAL, est destinée au dépôt et à la diffusion de documents scientifiques de niveau recherche, publiés ou non, émanant des établissements d'enseignement et de recherche français ou étrangers, des laboratoires publics ou privés. 


\title{
Crustal structure and gravity anomalies beneath the Rif, northern Morocco: implications for the current tectonics of the Alboran region
}

\author{
Carole Petit, ${ }^{1}$ Laetitia Le Pourhiet,${ }^{1,2}$ Bruno Scalabrino, ${ }^{1}$ Michel Corsini, ${ }^{1}$ \\ Mickaël Bonnin ${ }^{1}$ and Adrien Romagny ${ }^{1}$ \\ ${ }^{1}$ Geoazur, CNRS-UNS-IRD, 250 rue Albert Einstein, F-06560 Valbonne, France. E-mail: petit@geoazur.unice.fr \\ ${ }^{2}$ ISTeP, CNRS-UPMC, 4 Place Jussieu, F-75005 Paris, France
}

Accepted 2015 April 15. Received 2015 April 15; in original form 2015 January 13

\begin{abstract}
SUMMAR Y
We analyse Bouguer anomaly data and previously published Moho depths estimated from receiver functions in order to determine the amount of isostatic compensation or uncompensation of the Rif topography in northern Morocco. We use Moho depth variations extracted from receiver function analyses to predict synthetic Bouguer anomalies that are then compared to observed Bouguer anomaly. We find that Moho depth variations due to isostatic compensation of topographic and/or intracrustal loads do not match Moho depth estimates obtained from receiver function analyses. The isostatic misfit map evidences excess crustal root as large as $10 \mathrm{~km}$ in the western part of the study area, whereas a 'missing' crustal root of $\sim 5 \mathrm{~km}$ appears east of $4.3^{\circ} \mathrm{E}$. This excess root $/ \mathrm{missing}$ topography correlates with the presence of a dense mantle lid, the noticeable southwestward drift of the Western Rif area, and with a current surface uplift. We propose that a delaminated mantle lid progressively detaching westward or southwestward from the overlying crust is responsible for viscous flow of the ductile lower crust beneath the Rif area. This gives rise to isostatic uplift and westward drift due to viscous coupling at the upper/lower crust boundary. At the same time, the presence of this dense sinking mantle lid causes a negative dynamic topography, which explains why the observed topography is too low compared to the crustal thickness.
\end{abstract}

Key words: Gravity anomalies and Earth structure; Continental tectonics: compressional; Dynamics of lithosphere and mantle; Kinematics of crustal and mantle deformation; Africa.

\section{INTRODUCTION}

Topography in orogenic belts results from complex interactions between crustal tectonics, mantle dynamics and surface erosion, all processes leading to isostatic re-adjusments. Whereas crustal thickening due to tectonic shortening is often thought to be the dominant process driving topography growth, several studies have stressed that sublithospheric mantle movements can generate dynamic topographic support (e.g. Lithgow-Bertelloni \& Silver 1998; Boschi et al. 2010; Braun 2010). Alternatively, the presence of an anomalously thin lithosphere beneath some mountain ranges has also been inferred to explain an excess topography with respect to known Moho depths, in a static sense, because of a positively buoyant asthenosphere (e.g. Missenard et al. 2006; Petit et al. 2008).

Assessing the respective role of crustal and mantle dynamics in the present-day topography requires assembly of reliable data on the crust and lithosphere structures, particularly in actively deforming areas where both processes likely occur. In this paper, we focus on the role of crust and mantle dynamics of the present-day structure and kinematics of the Rif region, northern Morocco.
The Alboran region between the Eurasian and African plates undergoes active compressional and strike-slip deformation due to the still ongoing convergence between these two plates (e.g. Vernant et al. 2010; Pedrera et al. 2011). Several lines of evidence point at an active role of mantle (either continental or oceanic) processes in the recent tectonic history of this area. GPS data indicate that current horizontal kinematics of the Rif region are markedly different from the global Iberia-Africa convergence vectors (Vernant et al. 2010), which has led some authors to propose complex plate boundary geometries in this area (e.g. Bird 2003; Gutscher 2004), or to infer the presence of a westward-directed, increased mantle basal traction beneath it (Pérouse et al. 2010). There are several indications of recent (Pliocene) uplift of the internal Rif units coeval with normal faulting and extension in the Alboran sea, which cannot be easily related to the far-field compressional setting (Romagny et al. 2014). Most tomographic models evidence a dense mantle body trending almost vertically beneath the Rif and Betic systems (e.g. Boschi et al. 2010; Alpert et al. 2013; Bezada et al. 2013; Bonnin et al. 2014). Finally, splitting analyses show strikingly different fast polarization directions (FPD) beneath the western Rif 
and the surrounding areas (e.g. Diaz et al. 2010; Alpert et al. 2013), which have been explained by the presence of a stiff mantle slab sinking beneath the Rif (Alpert et al. 2013). Based on these observations, the links between the sublithospheric structure and recent tectonics of the Alboran region have been explained by three endmember models: continental mantle delamination (e.g. Seber $e t$ al. 1996; Calvert et al. 2000), convective removal of mantle lithosphere (e.g. Platt \& Vissers 1989; Platt et al. 2013) or slab retreat of either northward-verging (e.g. Jolivet et al. 2008) or southward-verging (e.g. Verges \& Fernandez 2012) oceanic subduction.

In summary, the Rif region displays evidences for recent uplift, large velocity contrasts in the mantle, and 'anomalous' westward surface velocities, which make it a good natural laboratory for investigating the relationships between mantle processes and surface horizontal and vertical motions.

In this study, we analyse Bouguer anomaly data jointly with published Moho depths picked from receiver functions (RF, Mancilla et al. 2012) in order to determine: (i) if the gravity signal is compatible with RF Moho depths, and (ii) if RF Moho depths compensate the topographic load in a local (Airy) or regional sense. Deviation from local isostasy (i.e. too large or too small crustal thickness compared to the topographic load) are compared with GPS data and recently obtained tomographic images. Spatial correlation between overthickened crust, fast mantle velocities, and anomalous westward drift in the Rif region allows us to propose a schematic model of the current structure and kinematics study area.

\section{GEOLOGICAL SETTING}

The Alboran region in the Western Mediterranean is characterized by curved mountain belts (Rif and Betics) surrounding the Alboran Sea basin, which is composed of an extended and intruded continental crust (e.g. Booth-Rea et al. 2007). The Rif orogen, Betic cordillera and Alboran Basin are located at the southwestern tip of the Alpine system and Western Mediterranean sea. These mountain belts were emplaced mostly in Late Eocene-Miocene times in a complex geodynamic framework involving the convergence between Eurasia and Africa (Chalouan et al. 2008 and references therein) and westward tectonic drift related to slab rollback (e.g. Royden 1993; Lonergan \& White 1997; Jolivet \& Faccenna 2000; Faccenna et al. 2004; Spakman \& Wortel 2004; Platt et al. 2013). In the case of the Rif mountain belt, the focus of this paper, it is generally agreed that the main structural and tectonic features are mostly the consequence of Alpine deformation, which overprinted and reactivated older (Variscan) structures (e.g. Chalouan et al. 2008; Rossetti et al. 2010). From south to north across the Rif system, from Fès to the Mediterranean coast (Fig. 1), several domains can be distinguished.

The African crust south of the Rif region is characterized by PlioQuaternary compressional deformation involving the south-vergent thrusting of the Prerif nappes above a Neogene foreland basin, the Gharb basin (an equivalent of the Guadalquivir basin in the Betics). This deformation is characterized by thrusts and fold-related faults affecting Quaternary formations and by moderate seismicity (Chalouan \& Michard 2004; Chalouan et al. 2014). Further north, the External Rif domain is characterized by thick nappes stacking $(>10 \mathrm{~km})$ and NW-SE oriented-folds formed in Early Jurassic to Middle Cenozoic sediments (Chalouan et al. 2008; Frizon de Lamotte et al. 2011). Northward, the flyschs domain named 'the Maghrebian Flyschs' corresponds to a thick sequence of turbiditic sediments of Early Cretaceous to Neogene age (Durand-Delga et al.
2000; Crespo-Blanc \& Frizon de Lamotte 2006). These turbiditic series have been tectonically deformed during the Middle-Late Miocene into a thick nappes stack (several kilometres). Structurally, this domain lies beneath the northern Internal Unit, overlies the southern External domain (Chalouan et al. 2008), and exposes locally back-thrusted nappes over the internal zone (Fig. 1; Chalouan et al. 1995).

The northern part of the Rif belt (Internal Rif) exposes the most internal units. This domain is composed of three different folded nappes (Chalouan et al. 2008), namely from south to north: (i) The 'Dorsale Calcaire', a complex tectonic domain displaying thrust sheets dominated by unmetamorphosed Triassic to Liassic carbonates, visible in the landscape as a sharp topographic whitish ridge (hence its name); (ii) The Ghomarides nappe, made of Palaeozoic to Early Mesozoic sediments and (iii) the Sebtides unit composed of meta-sediments (upper Sebtides), continental crust and upper mantle (lower Sebtides, Michard et al. 2006). The Beni Bousera massif in the lower Sebtides consists of serpentinites which were emplaced at the surface during an early Miocene exhumation episode (e.g. Sánchez-Rodríguez \& Gebauer 2000). It is overlained by granulites, gneiss and micaschists of the Upper Sebtide Units (e.g. Kornprobst 1974). In contrast to the Ghomaride nappes, the Sebtides unit has recorded a strong HP-LT alpine metamorphic event followed around $\sim 20$ Ma by a rapid exhumation associated with granitic intrusions and core-complex development (Michard et al. 2006). The Internal domain is also characterized by the presence of isolated Pliocene sedimentary basins (Fig. 1) uncomformably overlaying the Sebtides units and the Ghomaride nappes. These marine deposits are now at elevations comprised between 0 and $500 \mathrm{~m}$ above sea level and reflect recent (Pliocene to present) vertical movements of the Rif belt at rates of $0.01-0.03 \mathrm{~mm} \mathrm{yr}^{-1}$ (e.g. Chalouan et al. 1995; Romagny et al. 2014). Major shear zones, like the NE-SW trending Nekor and Jebha faults affect all these domains and where active during the Miocene (Benmakhlouf et al. 2012; Fig. 1).

\section{METHODS}

\subsection{Moho gravity grid from receiver function data}

Punctual Moho depths in the Rif region are taken from recently published receiver function analysis (RF) by Mancilla et al. (2012). Moho depths were estimated assuming a $V_{\mathrm{p}}$ value of $6.3 \mathrm{~km} \mathrm{~s}^{-1}$ determined from existing refraction profiles and by a grid search of the best-fitting $V_{\mathrm{p}} / V_{\mathrm{s}}$ ratio and Moho depth at each station. This study has imaged large crustal thickness variations beneath the Rif system, which was lately confirmed by a wider, high-resolution study encompassing the Rif, Betics and Alboran regions (Thurner et al. 2014). As Mancilla et al. (2012) point out, two possible Moho conversions occur beneath some stations of the central Rif, giving Moho depths of about 40 and more than $50 \mathrm{~km}$, respectively. We follow Mancilla et al. (2012) and select the shallowest Moho values in order to avoid an overestimation of the crustal thickness. We first tested the effect of the interpolation method on the Moho depth grid uncertainty. We use a Delaunay triangulation (DT) and nearest neighbour algorithm (NN) of the Generic Mapping Tools software (Wessel et al. 2013) to compute interpolated Moho depth grids with a resolution of 10 arcmin. A grid of Moho depth uncertainty is computed by adding errors arising from the gridding methods and uncertainties on Moho depth values computed from RF analyses. 

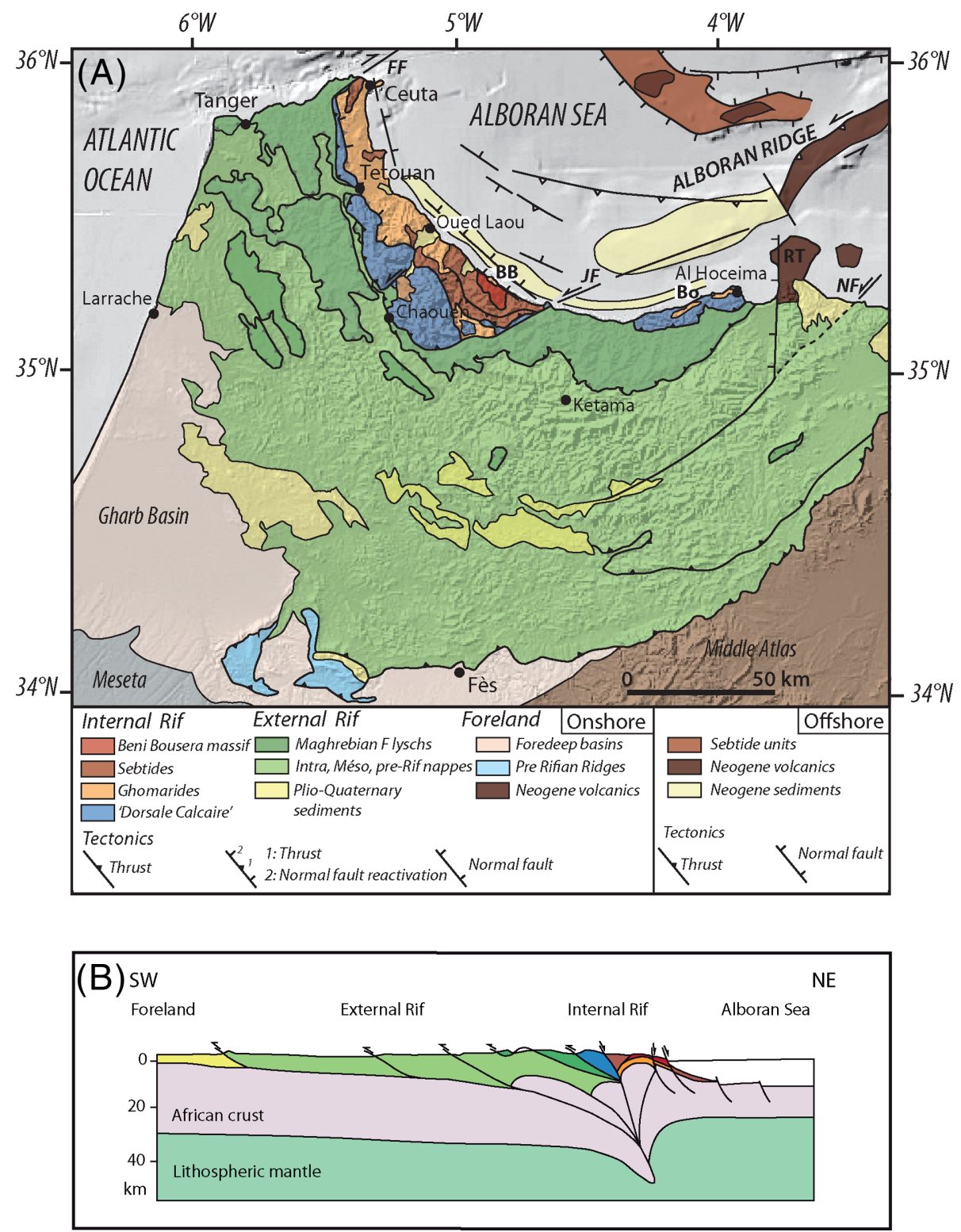

Figure 1. (a) Simplified structural map of the Rif and south Alboran sea (after Chalouan et al. 2008). BB, Beni Bousera massif; FF, Fahies fault; JF, Jebha Fault; NF, Nekor Fault; RT, Ras el Tarf. Solid line indicates the location of the cross-section drawn on (b). (b) Schematic crustal-scale cross-section after Michard et al. (2002) and Fullea et al. (2010) for surficial and deep structures, respectively.

\subsection{Comparison with Bouguer anomaly data}

We compute a synthetic Bouguer anomaly grid resulting from RF Moho depths (hereafter referred to as 'modelled Bouguer anomaly') and compare it to measured Bouguer anomaly values (hereafter referred to as 'observed Bouguer anomaly'). The observed Bouguer anomaly grid is interpolated from a set of field survey points provided by the Bureau Gravimétrique International (BGI). The complete Bouguer anomaly is computed from free-air gravity and topography data using a mean density of $2670 \mathrm{~kg} \mathrm{~m}^{-3}$ for nearsurface rocks. A residual grid of the difference between observed and modelled Bouguer anomaly grids is then computed and allows us to better evaluate density variations which cannot be attributed to Moho depth changes. The gravity residual is computed also for the larger Moho depths estimates at the three stations where double conversions were observed (Table 1).

\subsection{Computation of isostatic anomalies in a local or regional sense}

In order to assess what fraction of the Moho topography is due to the isostatic regional compensation of surface and subsurface loads, we compute the theoretical effect of topographic and intracrustal loads on the Moho deflection. To this purpose, we use a constant effective elastic thickness ( $T e$ ) of 0 (local isostasy) and $15 \mathrm{~km}$ and compute the Moho deflection (hereafter named 'isostatic Moho') using the flexure equation:

$D \nabla^{4} w+\left(\rho_{m}-\rho_{c}\right) g w=q$,

where $q$ is the topographic and subsurface load, $w$ is the deflection, $D$ is the flexural rigidity of the lithosphere (assumed constant), $g$ is the acceleration of gravity and $\rho_{\mathrm{m}}$ and $\rho_{\mathrm{c}}$ are mantle and crust densities. Subsurface loading is computed by converting the residual 
Table 1. Misfits to observed Bouguer anomaly, and local and regional isostatic models, for the stations where double Moho conversion were observed (Mancilla et al. 2012).

\begin{tabular}{|c|c|c|c|c|c|c|c|c|}
\hline \multirow{2}{*}{$\begin{array}{l}\text { Station } \\
\text { name }\end{array}$} & \multicolumn{2}{|c|}{ Moho depth values } & \multicolumn{2}{|c|}{$\begin{array}{c}\text { Misfit to Bouguer } \\
\text { Bouguer anomaly (mGal) }\end{array}$} & \multicolumn{2}{|c|}{$\begin{array}{l}\text { Isostatic Moho anomaly } \\
\text { (km) for } T e=0\end{array}$} & \multicolumn{2}{|c|}{$\begin{array}{l}\text { Isostatic Moho anomaly } \\
(\mathrm{km}) \text { for } T e=15 \mathrm{~km}\end{array}$} \\
\hline & Shallow Moho & Deep Moho & Shallow Moho & Deep Moho & Shallow Moho & Deep Moho & Shallow Moho & Deep Moho \\
\hline PVLZ & 35.1 & 52.0 & -134.27 & 37.39 & -3.11 & 18.22 & -4.80 & 16.49 \\
\hline M013 & 27.2 & 50.3 & 17.79 & 121.32 & 1.26 & 14.10 & 1.86 & 14.71 \\
\hline
\end{tabular}

gravity grid into a density contrast grid, assuming that the density contrasts are located in a $5-\mathrm{km}$-thick layer close to the surface. This is a reasonable assumption, since the location of these intracrustal loads is consistent with the surface geology and with the geological cross-section, which shows that large density contrast are restricted to the upper $5-10 \mathrm{~km}$ of the crust (see hereafter, Section 4 and Fig. 1). As an example, a residual of $50 \mathrm{mGal}$ will correspond to a density contrast of $\sim 240$ or $\sim 120 \mathrm{~kg} \mathrm{~m}^{-3}$ for a crustal layer thickness of 5 or $10 \mathrm{~km}$, respectively; both values will give in the same crustal load. The lithosphere flexural rigidity $D$ is related to its effective elastic thickness Te such as (e.g. Burov \& Diament 1995):

$D=\frac{E \cdot T e^{3}}{12\left(1-v^{2}\right)}$,

where $E$ and $v$ are the Young modulus and Poisson ratio, respectively. The $T e$ value of $15 \mathrm{~km}$ is chosen in order to avoid an overestimation of isostatic residuals, and corresponds to a hot continental lithosphere where the crust and mantle elastic lids are mechanically decoupled (Burov \& Diament 1995). A Non-isostatic Moho grid is then computed as the difference between the actual Moho depth (as taken from RF data) and the one predicted from a local or regional compensation of the topographic and subsurface loads. It can be interpreted as an excess or missing crustal root.

\subsection{Comparison with GPS data}

Large departures from local or regional isostatic equilibrium need to be dynamically supported in a fashion that must be compatible with both the kinematics and deformation of the region. In order to evaluate how present-day kinematics of the Rif area are correlated with crustal thickness variations, we compare the RF Moho depth grid with GPS velocities displayed in an Eurasia-fixed reference frame (Koulali et al. 2011).

\section{RESULTS}

\subsection{Moho depths, gravity anomalies and intracrustal loads}

We choose to use a Moho depth grid computed with the DT method for the rest of the analysis because it better preserves initial local Moho depths at station points (Fig. 2a). The difference in Moho depth estimates between both gridding methods (taking into account uncertainties in Moho depth determination from RF analyses) is of max. $5 \mathrm{~km}$ (Fig. 2b).

RF Moho depths display important E-W variations from more than $45 \mathrm{~km}$ in the western part of the Rif, to about $23 \mathrm{~km}$ in the eastern part. The transition from a thick $(>40 \mathrm{~km})$ crust to a thin one follows a NE-SW line that reach the coast at about $-4^{\circ} \mathrm{E}$ (Fig. 2a). South of $34^{\circ} \mathrm{N}$, the crustal thickness appears more homogeneous.
The arcuate shape of the Rif belt is well visible in the observed free-air and Bouguer anomaly maps, the latter displaying a zone of low gravity values extending from the Strait of Gibraltar to the longitude of $\sim 4^{\circ} \mathrm{W}$ (Figs $3 \mathrm{a}$ and $\mathrm{b}$ ). East of this meridian, the Bouguer anomaly is null or positive. Furthermore, gravity data evidence large Bouguer anomaly gradients, with a low value reaching $\sim-180 \mathrm{mGal}$ beneath the southern Rif and a high positive value of $\sim 70 \mathrm{mGal}$ near the coast at about $\sim 5^{\circ} \mathrm{W}$.

Moho depth variations from RF analyses only poorly explain the observed Bouguer anomaly data (Fig. 3c). Negative Bouguer anomaly values are predicted in the western part of the Rif, west of $-4.5^{\circ} \mathrm{W}$ and north of $34^{\circ} \mathrm{N}$, but RF Moho depths are too shallow to account for the negative peak of $-180 \mathrm{mGal}$ observed beneath the southwestern Rif. The high positive value of $70 \mathrm{mGal}$ observed in the central Rif near the coast is not reproduced either. More importantly, in the modelled Bouguer anomaly grid, the transition from negative to positive Bouguer anomaly is shifted westward by about $50 \mathrm{~km}$ with respect to observed Bouguer anomaly. This seems not to result from the gridding process, as the transition from low to high Bouguer anomaly in the modelled grid is well constrained thanks to the relatively dense station network around $-4^{\circ} \mathrm{E}, 35^{\circ} \mathrm{N}$.

As described above, a zone of high gravity residuals is observed at about $5^{\circ} \mathrm{W}, 35.3^{\circ} \mathrm{N}$. This high-density zone very likely corresponds to the ultramafic Beni Bousera massif (Fig. 1). An area of low gravity residuals appears south of $35^{\circ} \mathrm{N}$ and between $2^{\circ} \mathrm{W}$ and $5^{\circ} \mathrm{W}$. Although it is difficult to relate it to any observed surface structure, it could correspond to the place where the pile of Prerif nappes is the thickest, that is to a larger thickness of low-density sediments, although it could also be due to a local crustal thickening that is not resolved by the coarse RF Moho map. Consequently, it seems that part of Bouguer anomaly residuals result from intracrustal density variations linked to the tectonic history of the Rif area. If these intracrustal loads had caused a significant isostatic response, they would be somehow correlated with Moho depths variations, which is not the case. Consequently, intracrustal loads must be mostly supported by the lithosphere flexural rigidity.

\subsection{Anomalous crustal thickness in the Western Rif}

Even for a local compensation of the topography $(T e=0 \mathrm{~km})$, the isostatic Moho displays only smooth depth variations, very different from the sharp ones observed from receiver function analyses; increasing $T e$ to account for lithosphere flexural rigidity discussed in the previous paragraph render the Moho even smoother (Fig. 4a). Differences between RF and isostatic Moho grids reflect Moho depths changes (hereafter named 'anomalous Moho') that are not predicted by the isostatic compensation of crustal loads, even with a very conservative assumption of a constant $T e$ of $0-15 \mathrm{~km}$. These values are rather small for continental lithosphere but are reasonable given the domain is an active plate boundary where the contribution 


\section{A- Moho depth grid from RF (Delaunay Triangulation)}
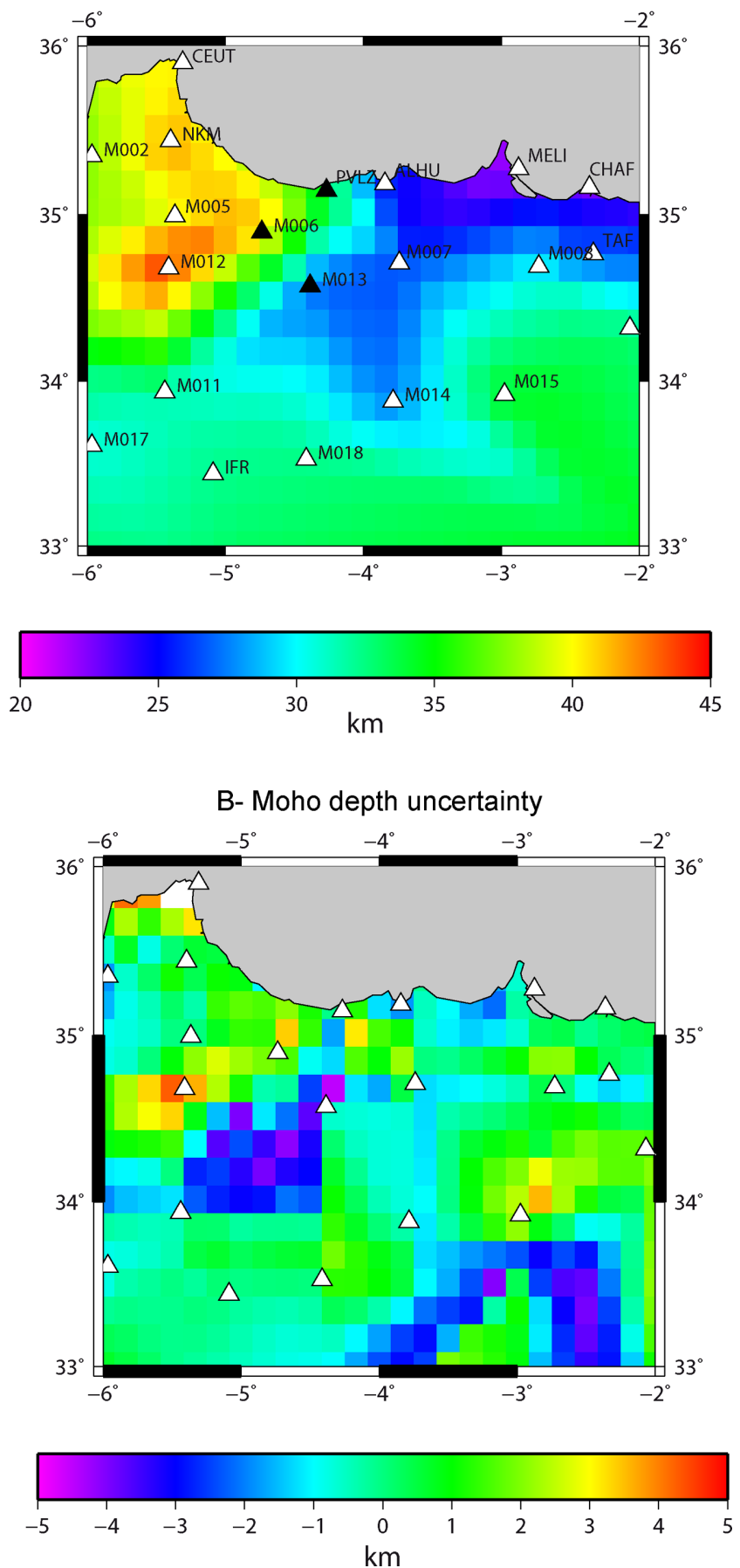

Figure 2. (a) Moho depth grids computed from receiver function (RF) analyses by Mancilla et al. (2012) using a Delaunay Triangulation (DT); (b) Moho depth uncertainty computed from RF uncertainty estimates (after Mancilla et al. 2012) and from estimates of errors arising from the gridding method (this study). Station names are indicated. Solid triangles are the three station where double Moho conversions were observed.

of the lithospheric mantle must be small (Burov \& Diament 1995). Moreover, we choose a low $T e$ because we do not want to underestimate the isostatic Moho topography: the larger Te, the lower the isostatic Moho topography. The anomalous Moho map (Fig. 4b) evidences an excess crustal root as large as $10 \mathrm{~km}$ in the western part of the study area, whereas a 'missing' crustal root of $\sim 5-10$ $\mathrm{km}$ appears east of $4.3^{\circ} \mathrm{W}$. In terms of isostatic compensation, it means that the crust is too thick in the western domain compared to observed topography, even taking into account the presence of buried crustal loads, and too thin in the eastern part of the Rif. Considering a lower crust density of 2700 and $2800 \mathrm{~kg} \mathrm{~m}^{-3}$ and a mantle density of $3200 \mathrm{~kg} \mathrm{~m}^{-3}$, the excess crustal root corresponds to a 'missing' topography of 800-1400 m. In other words, Moho depth variations due to isostatic compensation of topographic and/or intracrustal loads do not match Moho depth estimates obtained from receiver function analyses.

\subsection{Correlation between crustal thickness and current kinematics in the Western Rif}

West of $4.5^{\circ} \mathrm{E}$, GPS vectors show dominantly westward motions at rates varying between 4 and $7 \mathrm{~mm} \mathrm{yr}^{-1}$, whereas displacements east of this meridian are mostly directed towards the NW and are in general slower (3-6 $\mathrm{mm} \mathrm{yr}^{-1}$, Fig. 5a). When projecting the westward component of velocity vectors on a NS profile and comparing it to Moho depth values, the western domain shows a clear correlation between Moho depth variations and the length of the westward velocity component, with a correlation coefficient of $\sim 0.67$ (Fig. $5 b$ ). Both Moho depths and westward velocities progressively increase from south to north in the western domain up to the latitude of $\sim 35.5^{\circ} \mathrm{N}$, and then sharply decrease further north. However, no such correlation appears on the eastern domain, where the correlation coefficient is lower than 0.2 (Fig. 5c). Being aware that correlation does not mean causal relationship, we nevertheless suggest that crustal overthickening, rapid westward motion and current uplift of the Rif region reflects a single dynamic process possibly related to the mantle.

\section{COMPARISON WITH SEISMOLOGICAL DATA AND MODELS}

Recently established tomographic models of the western Mediterranean (Bezada et al. 2013; Timoulali et al. 2013; Bonnin et al. 2014; Palomeras et al. 2014) have imaged velocity perturbations at depths ranging between 0 and $600 \mathrm{~km}$. In Bonnin et al.'s (2014) paper, velocity anomalies are satisfyingly resolved down to depths of $\sim 230 \mathrm{~km}$ and $\sim 600 \mathrm{~km}$ for $150 \mathrm{~km}$ and $300-\mathrm{km}$-wide anomalies, respectively. Horizontal slices taken from their study, located in the upper mantle at approximately 70, 135 and $225 \mathrm{~km}$ (Fig. 6) show a large curved positive velocity anomaly, which extends vertically beneath the Betics and western Rif down to a depth of $700 \mathrm{~km}$ and is inferred to be either a delaminated mantle lid or the remnant of a retreating slab. This large velocity anomaly extends upward at lower crustal depths beneath the western Rif (Fig. 6), where it could be directly attached to the lower crust, as visible on short-period surface wave tomography models (e.g. Palomeras et al. 2014). Conversely, it seems to be detached from the crust by a low-velocity mantle layer in the rest of the Gibraltar arc. Tomographic images suggest that the excess crustal root evidenced by RF and gravity data beneath the western Rif is underlain by a large piece of dense mantle that is possibly sinking down and/or retreating westward. Whether it is the remnant of an oceanic slab or a part of the continental mantle is actually difficult to assess. However, its close connection with a region of overthickened crust favours the hypothesis of a continental mantle.

SKS splitting analyses show that beneath the Betics, eastern Rif and Northern Middle Atlas, most fast polarization directions (FPD) are consistently oriented NE-SW and abruptly turn to NW-SE 

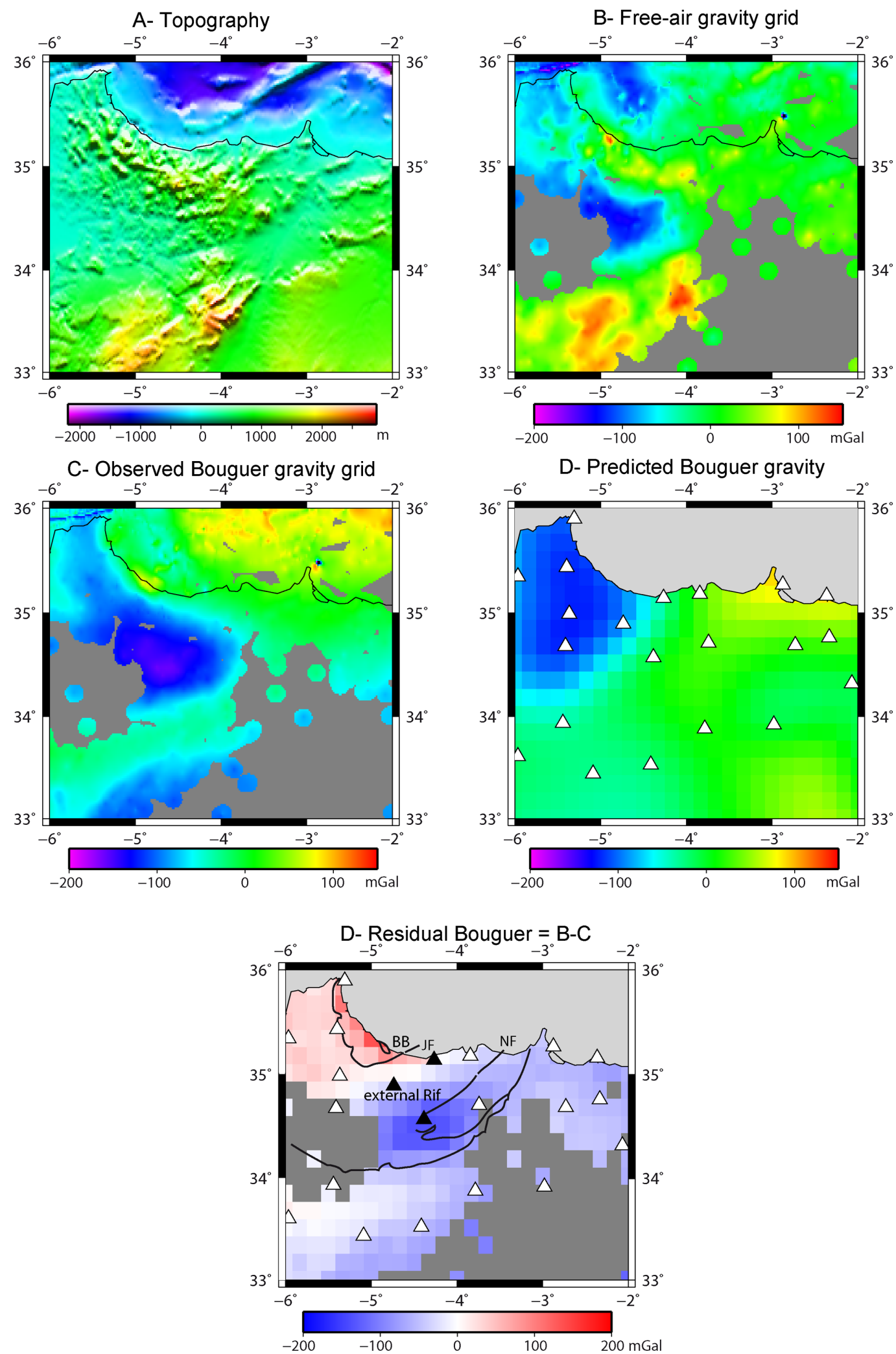

Figure 3. Topography, and gravity data and models. (a) Topography of the Rif area. (b) Observed Bouguer gravity from the BGI (Bureau Gravimétrique International) database; (c) Bouguer anomaly computed from observed (RF) Moho depths; (d) Residual (Observed - Computed) Bouguer anomaly grid. Solid lines are the main faults of the Rif system. Open triangles are seismic stations where RF were computed (after Mancilla et al. 2012). 


\section{A- Predicted isostatic Moho}

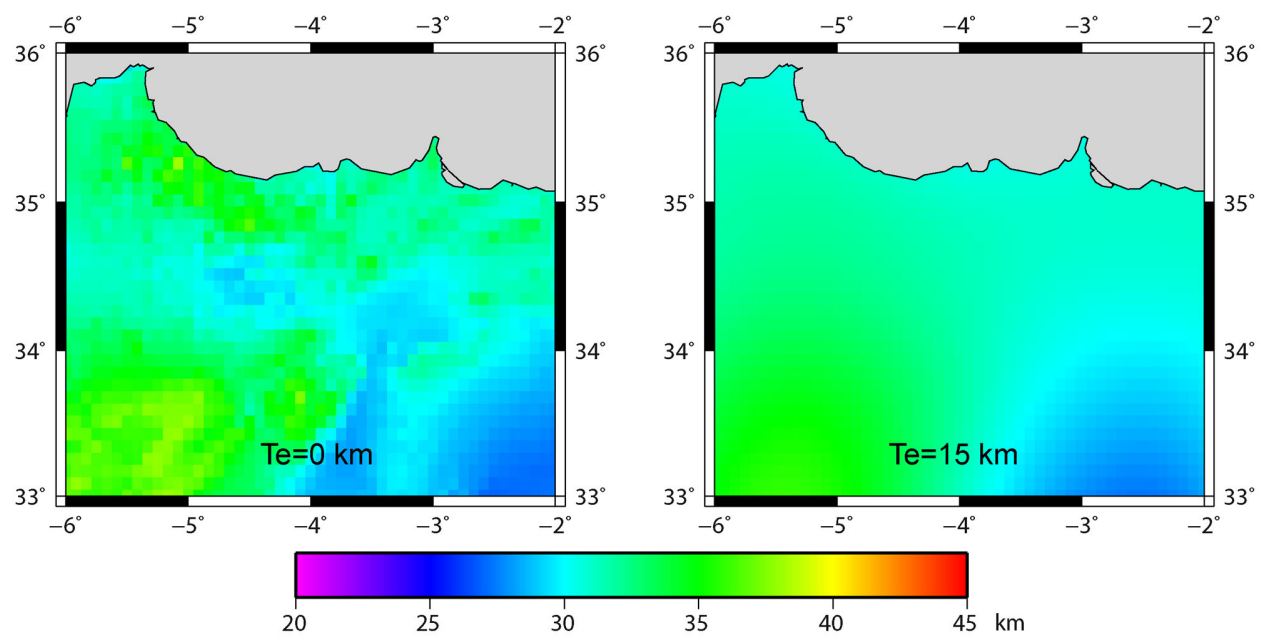

B- Non isostatic Moho

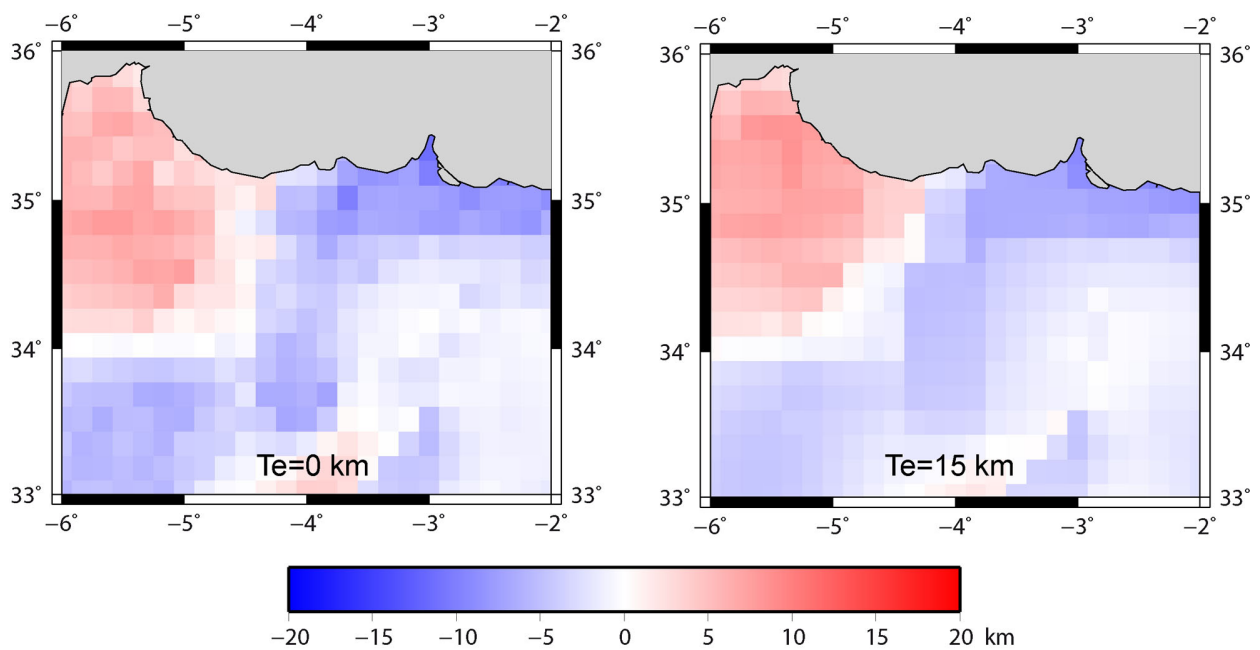

Figure 4. (a) Isostatic Moho depth computed from regional compensation of topographic and intracrustal loads with an effective elastic thickness (EET) of 0 (left) and $15 \mathrm{~km}$ (right); (b) non-isostatic Moho (a-b) for both EET values, computed as the difference between RF Moho depths and the isostatic Moho.

beneath the western Rif (e.g. Diaz et al. 2010; Alpert et al. 2013). The general NE-SW trend of most FPDs in the Betics and northwest Africa is consistent with a global, homogeneous mantle flow model where the FPD is due to the lattice preferred orientation (LPO) of olivine crystals parallel to the mantle flow direction (Alpert et al. 2013). According to this model, the abrupt $90^{\circ}$ turn of FPDs in the western Rif suggests that mantle flow is channelled laterally by a stiff, almost perpendicular mantle wall.

\section{DISCUSSION}

Given the Moho depth in the Western Rif, the topography should be some $800-1400 \mathrm{~m}$ higher than what is observed today assuming local isostasy, depending on the crust-mantle density contrast. Regional isostatic models predict an even higher topography. This negative topographic anomaly correlates at depth with the presence of a fast seismic velocity anomaly (Spakman \& Wortel 2004;
Alpert et al. 2013) that is often is interpreted either as a slab (e.g. Spakman \& Wortel 2004; Bokelmann et al. 2011) or as a delaminating continental lithosphere (e.g. Valera et al. 2009, 2011) or both (e.g. Pérouse et al. 2010; Thurner et al. 2014). Whatever the hypothesis chosen, a dense body is actively sinking in the viscous mantle and must cause a local downward deflection of the surface of the earth also called negative dynamic topography.

One would expect the surface of the Earth to dynamically subside in response to the suction force exerted by the sinking mantle (e.g. Houseman \& Molnar 1997). Instead, uplifted recent shallow marine sediments and low temperature thermochronology data indicate both active surface uplift and rock exhumation (Romagny et al. 2014). This suggests that the trivial interpretation of dynamic topography coeval with surface subsidence does not explain geological observations.

Indeed, when the crust and mantle are coupled, downward pull from the mantle correlates with true subsidence of the surface (Molnar \& Houseman 2013), because the whole crust is pulled 

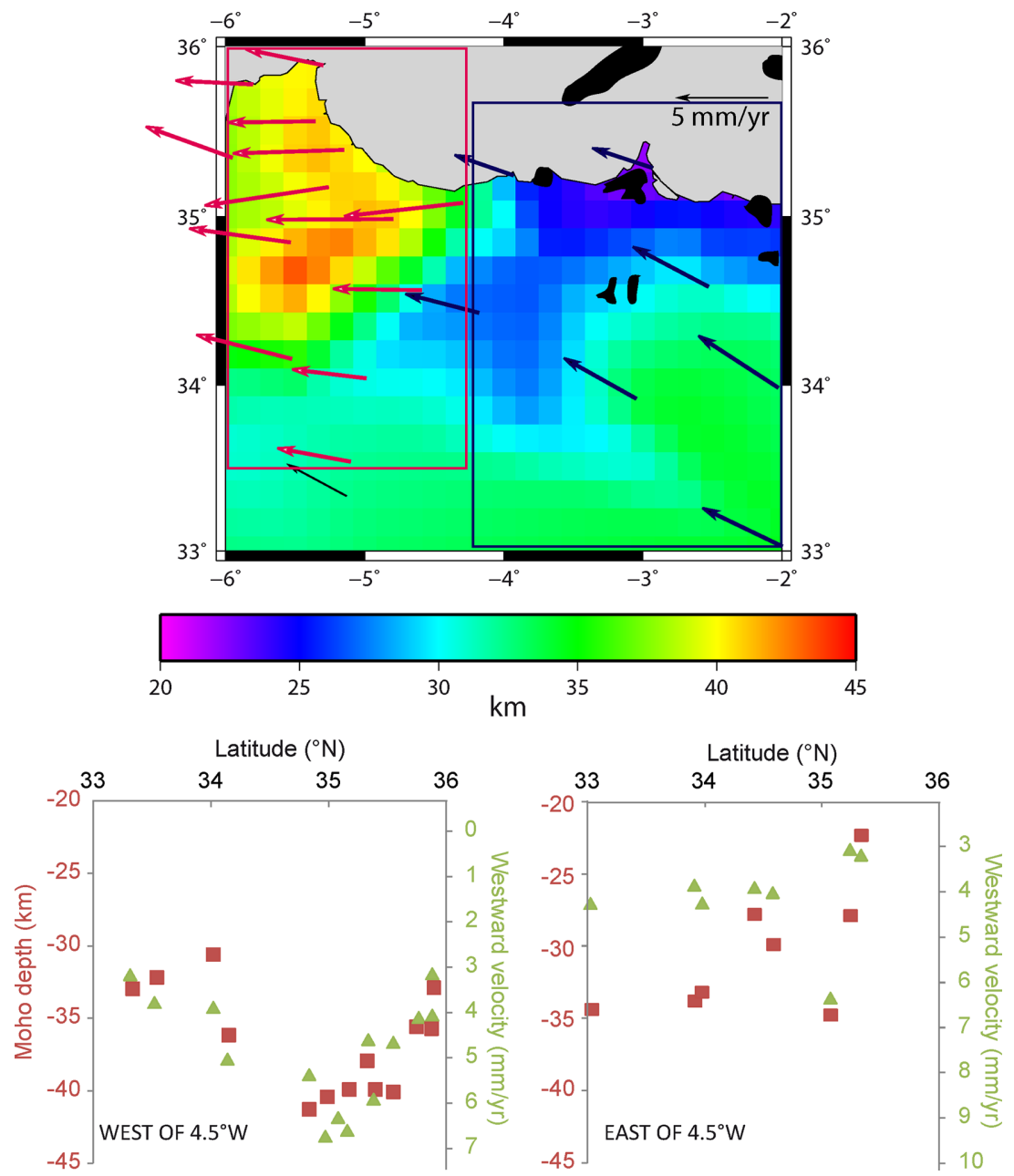

Figure 5. Comparison between Moho depths and GPS motions in an Eurasia-fixed reference frame (after Mancilla et al. 2012 and Koulali et al. 2011 , respectively). (a) Moho depths, seismicity and GPS vectors. Insets show the location of the two areas where correlations were determined. Red and blue arrows correspond to the lower left and right panels, respectively. (b) N-S profile of Moho depths (red squares) and westward components of GPS vectors (green triangles) on the western domain; (c) same profile for the eastern domain.

downwards by the sinking mantle. However, in a thick post-orogenic crust, negative dynamic topography might correlate with net surface uplift. Indeed, the suction forces of the sinking lithosphere combined with crust-mantle decoupling causes a dynamic crustal root building that is compensated by net surface uplift (Le Pourhiet et al. 2006). This mechanism is valid for both Rayleigh-Taylor instabilities (Göğüş \& Pysklywec 2008; Molnar \& Houseman 2013) and true delaminating lithosphere (Le Pourhiet et al. 2006; Gögüş \& Pysklywec 2008; Valera et al. 2011). It is worth noting that this model is quite different from the channel flow model proposed by Clark \& Royden's (2000). Indeed, in their model, the lower crust is expulsed eastward from below the Tibet plateau due to a large $\sim$ WE lithostatic pressure gradient, while the crustal thickness of the plateau is maintained because of the still on-going convergence between India and Eurasia. Hence, the lower crust is squeezed vertically and passively flows towards areas of lower lithostatic pressure ('Passive crustal flow,' Fig. 7a). Initially low, flat areas are uplifted, and normal faults develop on the plateau with dips towards the area of low topography. In our conceptual lower crustal flow model (based on numerical experiment performed and described in details in Le Pourhiet et al. 2006), the lower crust flows to fill the void created by the sinking mantle and causes isostatic uplift by actively thickening the crust ('Active crustal flow,' Fig. 7b). Normal faults develop in areas of originally low topography and dip towards the area of high topography, but still in the direction of the lower crustal flow.

All the afore-mentioned numerical models agree that the lower crust low viscosity channel must be thick $(>15 \mathrm{~km})$ and its viscosity very low ( $\left.<10^{21} \mathrm{~Pa} \mathrm{~s}\right)$ for this uplift mechanism to occur. Assuming locally that the lower part of the crust is not made of typical lower crustal rocks but rather of weak material seems a reasonable hypothesis to make. The alpine nappe stacking must indeed have conferred an initial inverse thermo-rheological stratification to the crust (Huet et al. 2011) as attested by the exhumation of the high grade meta-pelitics units within metamorphic core complexes in the internal zones of the Betics and the Rif (e.g. Michard et al. 2006).

It is worth noting also that differential isostatic response to erosion, due to the presence of high-density rocks in the Beni Bousera area, can contribute to surface uplift as the isostatic response is larger when the density contrast between the eroded material and the underlying mantle is low (Braun et al. 2014). Given the relatively small size of the massif compared to the Rif Chain, it is unlikely 

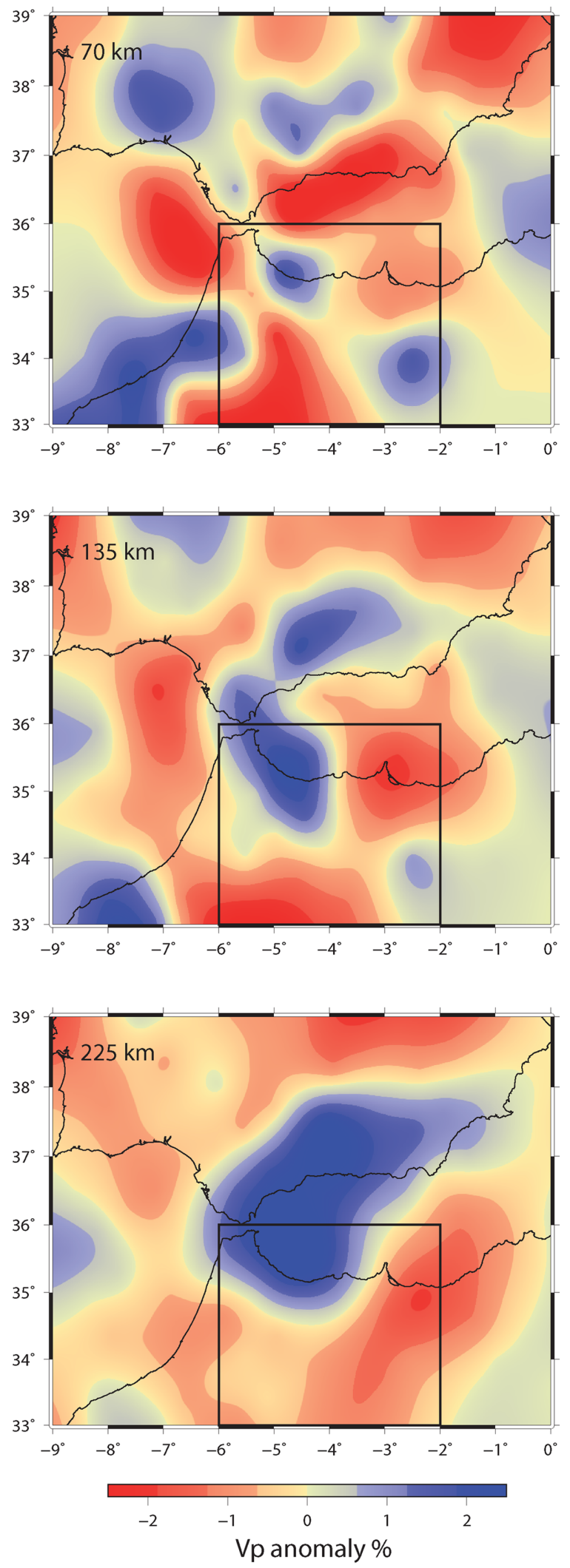

Figure 6. $P$-wave tomographic slices at 70,135 and $225 \mathrm{~km}$ depth, respectively (after Bonnin et al. 2014) in the Alboran region. Rectangle shows the extent of the Bouguer and Moho maps presented in this study (Figs 2-5). that this process can account for the total uplift rate of the whole Rif area; it is even not the highest part of the Rif belt (Fig. 3).

Comparing the shape of the Moho with various available numerical models of delamination (e.g. Le Pourhiet et al. 2006; Göğüş \& Pysklywec 2008; Valera et al. 2011; Saleeby et al. 2012) and Rayleigh-Taylor instabilities (Göğüş \& Pysklywec 2008; Molnar \& Houseman 2013), the observed step shape of the Moho in the study area is more compatible with a local delamination rather than a Rayleigh Taylor instability. All thermo-mechanical models of lithospheric delamination are indeed generally accompanied by the formation of an asymmetric crustal root that is maintained by the inward return flow of the asthenosphere on the steep side, and by the viscous drag of lithosphere on the gently dipping side (Fig. 8a).

Moreover, numerical models of true delaminating lithosphere indicate that a few million years after the mantle lithosphere has been removed, the newly formed lithosphere is characterized by partial melting, subsidence and lack of major normal faults associated to crustal thinning (Le Pourhiet et al. 2006; Göğüş \& Pysklywec 2008), which is consistent with the low topography, the thin crust and the magmatic activity of the Alboran Sea basin. The delamination models also have the advantage over Rayleigh-Taylor instability to predict active shortening shifted towards the "fore-land" as compared to maximum topography (Le Pourhiet et al. 2006; Göğüş \& Pysklywec 2008; Saleeby et al. 2012; Figs $8 \mathrm{a}$ and b), which compares well with the active deformation in the external zones.

Finally, the delamination model also predicts the double $\mathrm{P}-\mathrm{S}$ conversion visible at Moho depths on receiver functions, precisely at the places where the crust is thickest (Mancilla et al. 2012). This double conversion might reflect the presence of a double continental Moho resulting from the viscous drag of lower crust attached to the sinking mantle lid (Fig. 8a). This interpretation was also proposed by Thurner et al. (2014). Interestingly enough, this double conversion is also displayed in the receiver functions at the hinge of the delaminated lithosphere beneath the Sierra Nevada (California) ( Frassetto et al. 2011).

In the case of the Rif and Alboran basin, inception of continental lithosphere delamination might have been favored also by the southward retreat of the former oceanic slab attached to the African Tethyan margin. The smooth transition from subduction to delamination rather than abrupt slab break-off can be enabled by a weak and thick lower crust (Yamato et al. 2008; Magni et al. 2013). In the Betic-Rif system, this thick and weak lower crust could well be the metapelites units found today in the internal zones (Figs $1 \mathrm{~b}$ and $8 \mathrm{a}$ ). These sedimentary rocks were indeed overprinted with Upper Oligocene-Early Miocene syn-orogenic metamorphism with a NW-SE to N-S trending stretching lineation, and subsequently overprinted by LP-HT metamorphism in the late Miocene associated with the exhumation of metamorphic units (Jolivet et al. 2008). The post-orogenic signature could mark the transition from subduction to delamination as evidenced by the change in magma signature at around $6 \mathrm{Ma}$ (Duggen et al. 2003). The $10 \mathrm{Myr}$ delay between the initiation of stretching and the onset of high $\mathrm{K}$ volcanism is within the time span needed to initiate the delamination and sinking of continental lithosphere in numerical models (e.g. Le Pourhiet et al. 2006; Göğüş \& Pysklywec 2008; Valera et al. 2011).

The local weakening of the crust due to heating, volcanism and the difference in crustal thickness can act as a crustal-scale weakness localizing the active strike slip deformation (Le Pourhiet et al. 2014). Anomalous westward drift of the western Rif region (Fig. 4) is possibly due to viscous coupling between the upper and lower crust, the latter flowing towards the hinge of the sinking mantle lid. 


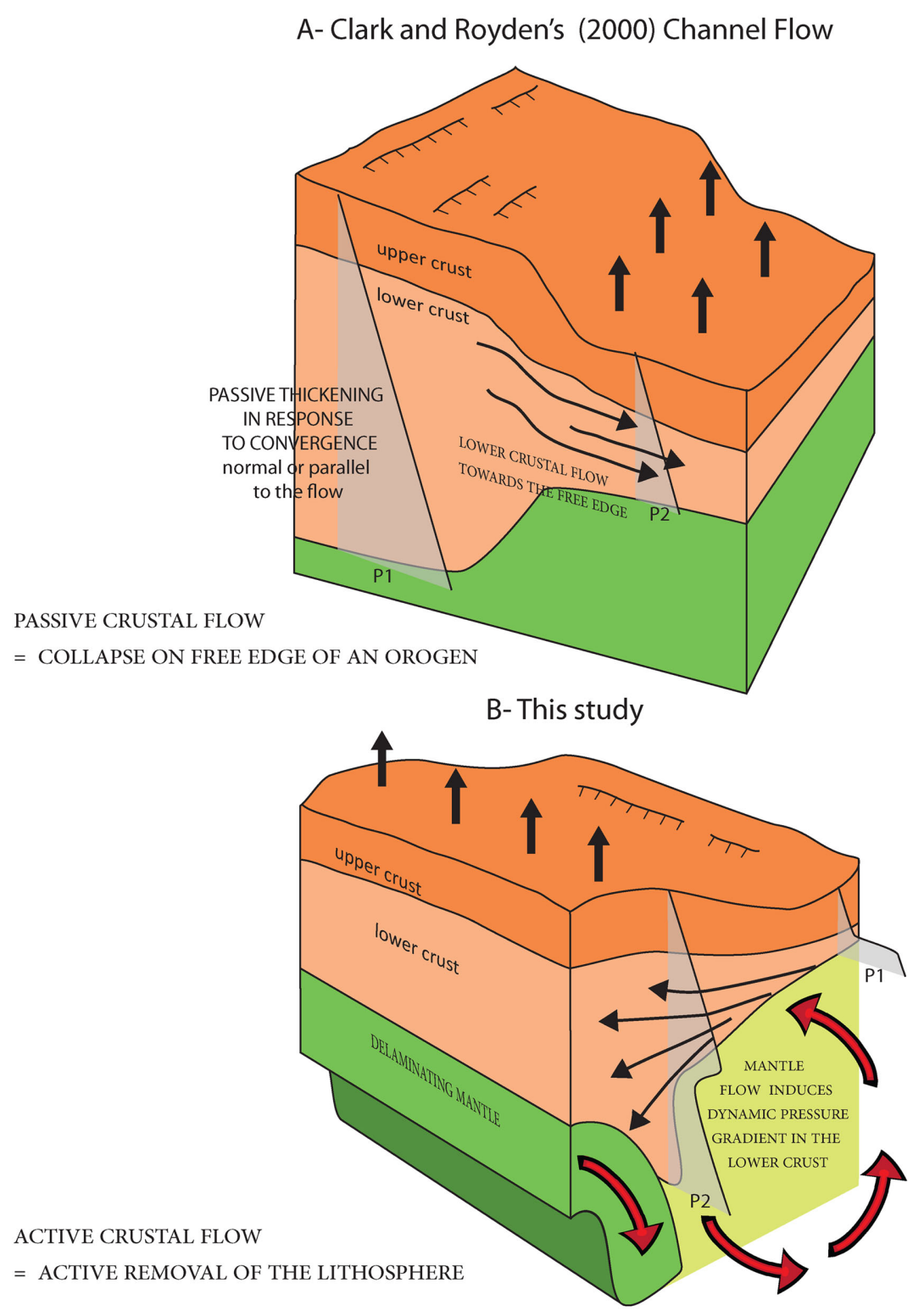

Figure 7. (a) Scheme of the channel flow model by Clark \& Royden (2000) where the crust inflow is driven by convergence; ductile lower crust is passively expelled from the uplifted areas towards low topography ones due to the large lithostatic pressure gradient (grey triangles). (b) Our model of active crustal flow. Mantle removal drags the lower crust downwards and sucks it to fill the void created above the mantle hinge. Asthenosphere flow in delaminated areas creates dynamic pressure gradients that promote lower crustal flow.

\section{CONCLUSIONS}

Given crustal thickness provided by RF data, we estimated the amount of 'missing' topography (in a local isostatic sense) in the Western Rif at $1000 \pm 500 \mathrm{~m}$ depending on the assumed crustmantle density contrast, i.e. twice to four times lower than the actual Rif highest elevation ( $>2000 \mathrm{~m}$ ). Therefore, without this negative dynamic effect, the Rif topography would be higher by $25-75$ per cent compared to its actual elevation.

Integrating gravity data, crustal thickness from RFs, seismic tomography, GPS and geological models, we propose that local thickening of the crust corresponds to the dynamic response to the delaminated mantle lid that is progressively detaching westward or southwestward from the overlying crust.

In this model, provided the lower crust is sufficiently buoyant and weak, the inward flow of lower crust towards the mantle hinge can cause a positive isostatic topography that is larger than the negative dynamic topography created by the sinking mantle lid. According to this hypothesis, the long wavelength Rif topography can be decomposed into two components: a positive isostatic response (uplift) due to the drag of lower crust beneath the Internal Rif and a negative dynamic component due to the downwelling of the continental mantle.

\section{ACKNOWLEDGEMENTS}

The authors are grateful to Guust Nolet and Muriel Gerbault for their very enthusiastic inputs to this study. Mickael Bonnin benefited from financial support by the ERC (ERC/Advanced\#226837). Bouguer anomaly data used in this study are available upon request at the Bureau Gravimetrique International 

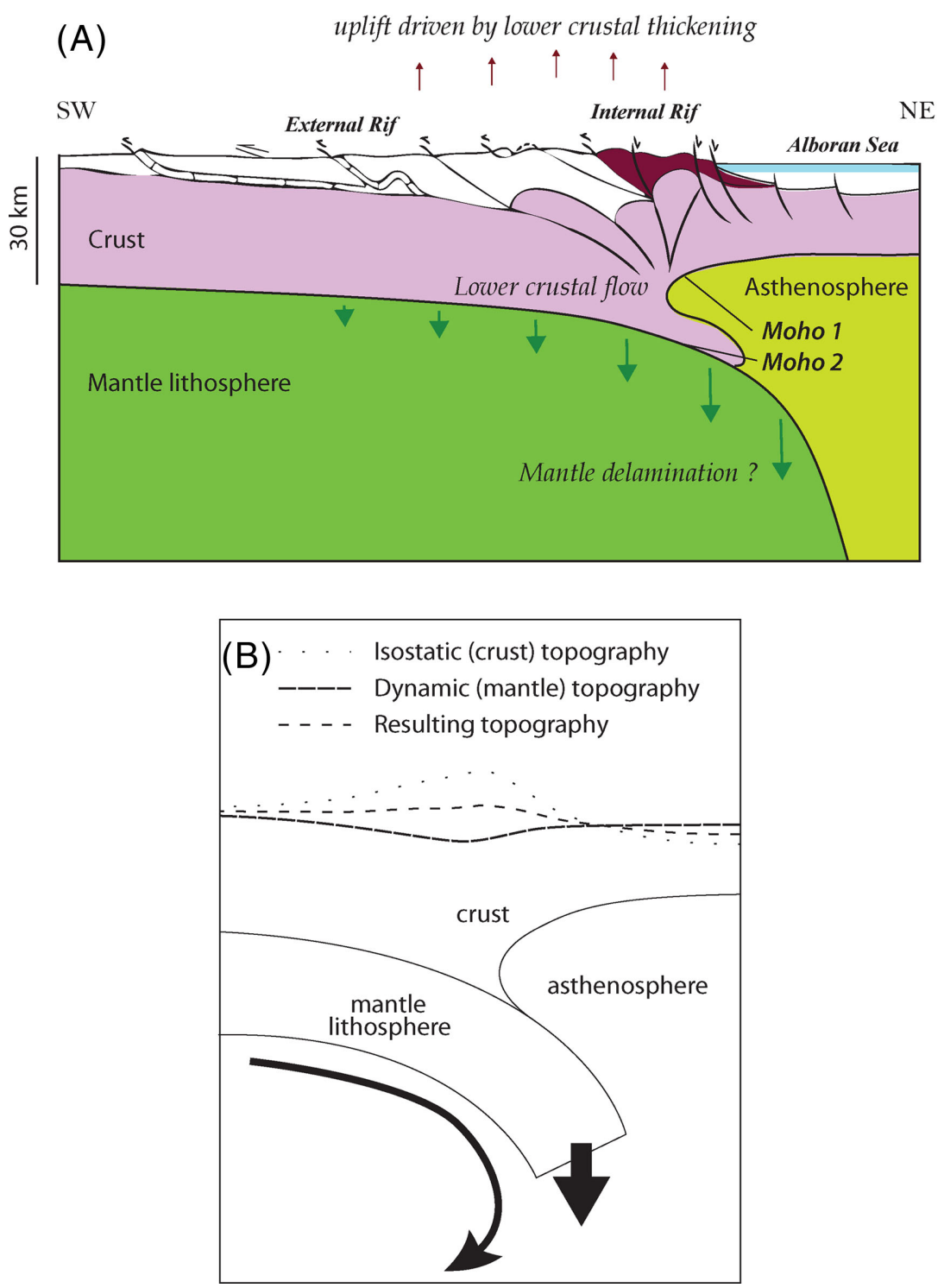

Figure 8. (a) Interpretative scheme of crust and mantle dynamics along a NE-SW cross-section of the Western Rif and Alboran domain (see text for explanations). The interpretative cross-section was drawn after Michard et al. (2002) and Fullea et al. (2010) for surficial and deep structures, respectively (see Fig. 1b). Moho1 and Moho2 refer to the two possible Moho conversions visible on some RFs (Mancilla et al. 2012). (b) Schematic explanation of the relationship between mantle delamination, lower crustal thickening, and isostatic and dynamic topography.

(http://bgi.omp.obs-mip.fr). Constructive comments by Jean Braun, Cynthia Ebinger (reviewers) and Stéphane Labrosse (editor) were greatly appreciated.

\section{REFERENCES}

Alpert, L.A., Miller, M.S., Becker, T.W. \& Allam, A.A., 2013. Structure beneath the Alboran from geodynamic flow models and seismic anisotropy, J. gophys. Res., 118, 1-13.

Benmakhlouf, M., Galindo-Zaldivar, J., Chalouan, A., Sanz de Galdeano, C., Ahmamou, M. \& Lopez-Garrido, A.C., 2012. Inversion of transfer faults: the Jebha-Chrafate fault (Rif, Morocco), J. Asian Earth Sci., 7374, 33-43.

Bezada, M.J., Humphreys, E.D., Toorney, D.R., Harnafi, M., Davila, J.M. \& Gallart, J., 2013. Evidence for slab rollback in westernmost Mediterranean from improved upper mantle imaging, Earth planet. Sci. Lett., 368, 51-60. Bird, P., 2003. An updated digital model of plate boundaries, Geochem. Geophys. Geosyst., 4, doi:10.1029/2001GC000252.
Bokelmann, G., Maufroy, E., Buontempo, L., Morales, J. \& Barruol, G., 2011. Testing oceanic subduction and convective removal models for the Gibraltar arc: seismological constraints from dispersion and anisotropy, Tectonophysics, 502(1), 28-37.

Bonnin, M., Nolet, G., Villaseñor, A., Gallart, J. \& Thomas, C., 2014. Multiple-frequency tomography of the upper mantle beneath the African/Iberian collision zone, Geophys. J. Int., 198, 1458-1473.

Booth-Rea, G., Ranero, C.R., Martinez-Martinez, J.M. \& Grevemeyer, I., 2007. Crustal types and tertiary tectonic evolution of the Alboran Sea, Western Mediterranean, Geochem. Geophys. Geosyst., 8, doi: 10.1029/2007GC001639.

Boschi, L., Faccenna, C. \& Becker, T.W., 2010. Mantle structure and dynamic topography in the Mediterranean basin, Geophys. Res. Lett., 37, doi:10.1029/2010GL045001.

Braun, J., 2010. The many surface expressions of mantle dynamics, Nat. Geosci., 3, 825-833.

Braun, J., Simon-Labric, T., Murray, K.E. \& Reiners, P.W., 2014. Topographic relief driven by variations in surface rock density, Nature Geoscience, 7, 534-540. 
Burov, E.B. \& Diament, M., 1995. The effective elastic thickness (Te) of continental lithosphere: what does it really mean?, J. geophys. Res., 100, 3905-3927.

Calvert, A., Sandvol, E., Seber, D., Barazangi, M., Roecker, S., Mourabit, T., Vidal, F., Alguacil, G. \& Jabour, N., 2000. Geodynamic evolution of the lithosphere and upper mantle beneath the Alboran region of the western Mediterranean: constraints from travel time tomography, J. geophys. Res., 105, $10871-10878$.

Chalouan, A. \& Michard, A., 2004. The Alpine Rif Belt (Morocco): a case of mountain building in a subduction-subduction-transform fault triple junction, Pure appl. Geophys., 161, 489-519.

Chalouan, A., Ouazani Touhami, A., Mouhir, L., Saji, R. \& Benmakhlouf, M., 1995. Les failles normales à faible pendage du Rif interne (Maroc) et leur effet sur l'amincissement crustal du domaine d'Alboran, Geogaceta, 17, 107-109.

Chalouan, A., Michard, A., El Kadiri, K., Negro, F., Frizon de Lamotte, D. $\&$ Saddiqi, O., 2008. The Rif Belt, in Continental Evolution: The Geology of Morocco, pp. 203-302, eds Michard, A., Chalouan, A., Saddiqi, O. \& Frizon de Lamotte, D., Springer.

Chalouan, A. et al., 2014. Active faulting in the frontal Rif Cordillera (Fes region, Morocco): constraints from GPS data, J. Geodyn., 77, 110-122.

Clark, M.K. \& Royden, L.H., 2000. Topographic ooze: building the eastern margin of Tibet by lower crustal flow, Geology, 28, 703-706.

Crespo-Blanc, A. \& Frizon de Lamotte, D., 2006. Structural evolution of the external zones derived from the flysch trough and the South Iberian and Maghrebian paleomargins around the Gibraltar arc: a comparative study, Bull. Soc. Geol. France, 177, 267-282.

Diaz, J. et al., 2010. Mantle dynamics beneath the Gibraltar arc (western Mediterranean) from shear-wave splitting measurements on a dense seismic array, Geophys. Res. Lett., 37, L18304, doi:10.1029/2010GL0044201.

Duggen, S., Hoernle, K., Van Den Bogaard, P., Rüpke, L. \& Morgan, J.P., 2003. Deep Roots of the Messinian Salinity Crisis, Nature, 422, 602-606.

Durand-Delga, M., Rossi, P., Olivier, P. \& Puglisi, D., 2000. Situation structurale et nature ophiolitique de roches basiques jurassiques associées aux flyschs maghrébins du Rif (Maroc) et de Sicile (Italie), C.R. Acad. Sci., 331, 29-38.

Faccenna, C., Piromallo, A., Crespo-Blanc, A., Jolivet, L. \& Rossetti, F., 2004. Lateral slab deformation and the origin of the Mediterranean arcs, Tectonics, 23, TC1012, doi:10.1029/2002TC001488.

Frassetto, A.M., Zandt, G., Gilbert, H., Owens, T.J. \& Jones, C.H., 2011. Structure of the Sierra Nevada from receiver functions and implications for lithospheric foundering, Geosphere, 7(4), 898-921.

Frizon de Lamotte, D., Caulin, C., Mouchot, N., Wrobel-Daveau, J.-C., Blanpied, C. \& Ringenbach, J.-C., 2011. The southernmost margin of the Tethys realm during the Mesozoic and Cenozoic: initial geometry and timing of inversion processes, Tectonics, 30, doi:10.1029/2010TC002691.

Fullea, J., Fernandez, M., Alfonso, J.C., Verges, J. \& Zeyen, H., 2010. The structure and evolution of the lithosphere-asthenosphere boundary beneath the Atlantic-Mediterranean Transition Region, Lithos, 120, 74 95.

Göğüş, Oğuz H. \& Pysklywec, R.N., 2008. Near-surface diagnostics of dripping or delaminating lithosphere, J. geophys. Res., 113, doi: 10.1029/2007JB005123.

Gutscher, M.-A., 2004. What caused the Great Lisbon Earthquake?, Science, 305, 1247-1248.

Houseman, G.A. \& Molnar, P., 1997. Gravitational (Rayleigh-Taylor) instability of a layer with non-linear viscosity and convective thinning of continental lithosphere, Geophys. J. Int., 128, 125-150.

Huet, B., Le Pourhiet, L., Labrousse, L., Burov, E. \& Jolivet, L. 2011. Postorogenic extension and metamorphic core complexes in a heterogeneous crust: the role of crustal layering inherited from collision, Application to the Cyclades (Aegean domain). Geophys. J. Int., 184(2), 611-625.

Jolivet, L. \& Faccenna, C., 2000. Mediterranean extension and the AfricaEurasia collision, Tectonics, 19, 1095-1106.

Jolivet, L. et al., 2008. Subduction, convergence and the mode of backarc extension in the Mediterranean region, Bull. Soc. Geol. France, 179, 525550
Kornprobst, J., 1974. Notes et Mémoires du Service Géologique, Vol. 251, Maroc, $256 \mathrm{pp}$.

Koulali, A. et al., 2011. New GPS constraints on active deformation along the Africa-Iberia plate boundary, Earth planet. Sci. Lett., 308, 211-217.

Le Pourhiet, L., Gurnis, M. \& Saleeby, J., 2006. Mantle instability beneath the Sierra Nevada Mountains in California and Death Valley extension, Earth planet. Sci. Lett., 251, 104-119.

Le Pourhiet, L., Huet, B. \& Traoré, N., 2014. Links between long-term and short-term rheology of the lithosphere: insights from strike-slip fault modelling, Tectonophysics, 631, 146-159

Lithgow-Bertelloni, C. \& Silver, P.G., 1998. Dynamic topography, platedriving forces and the African superswell, Nature, 395, 269-272.

Lonergan, L. \& White, N., 1997. Origin of the Betic-Rif mountain belt, Tectonics, 16, 504-522.

Magni, V., Faccenna, C., Van Hunen, J. \& Funiciello, F., 2013. Delamination vs. break-off: the fate of continental collision, Geophys. Res. Lett., 40, 285-289.

Mancilla, F. et al., 2012. Crustal thickness variations in northern Morocco, J. geophys. Res., 117, doi:10.1029/2011JB008608.

Michard, A., Chalouan, A., Feinberg, H., Goffé, B. \& Montigny, R., 2002. How does the Alpine belt end between Spain and Morocco?, Bull. Soc. Geol. Fr., 173, 3-15.

Michard, A., Negro, F., Saddiqi, O., Bouybaouene, M., Chalouan, A., Montigny, R. \& Goffé, B., 2006. Pressure-temperature-time constraints on the Maghrebide mountain building: evidence from the RifBetic transect (Morocco, Spain), Algerian correlations, and geodynamic implications, Comptes Rendus Geosci., 338, 92-114.

Missenard, Y., Zeyen, H., Frizon de Lamotte, D., Leturmy, P., Petit, C., Sébrier, M. \& Saddiqi, O., 2006. Crustal versus asthenospheric origin of relief of the Atlas Mountains of Morocco, J. geophys. Res., 111, doi:10.1029/2005JB003708

Molnar, P. \& Houseman, G.A., 2013. Rayleigh-Taylor instability, lithospheric dynamics, surface topography at convergent mountain Belts, and Gravity Anomalies, J. geophys. Res.: Solid Earth, 118, 2544-2557.

Palomeras, I., Thurner, S., Levander, A., Liu, K., Villaseñor, A., Carbonell, R. \& Harnafi, M., 2014. Finite-frequency Rayleigh wave tomography of the western Mediterranean: mapping its lithospheric structure, Geoch. Geophys. Geosyst., 15, doi:10.1002/2013GC004861.

Pedrera, A. et al., 2011. Is there an active subduction beneath the Gibraltar orogenic arc?, Constraints from Pliocene to present-day stress field. $J$. Geodyn., 52, 83-96.

Pérouse, E., Vernant, P., Chéry, J., Reilinger, R. \& McClusky, S., 2010. Active surface deformation and sub-lithospheric processes in the western Mediterranean constrained by numerical models, Geology, 38, 823-826.

Petit, C., Tiberi, C., Deschamps, A. \& Déverchère, J., 2008. Teleseismic traveltimes, topography and lithospheric structure across western Mongolia, Geophys. Res. Lett., 35, doi:10.1029/2008GL033993.

Platt, J.P. \& Vissers, R.L.M., 1989. Extensional collapse of thickened continental lithosphere: a working hypothesis for the Alboran Sea and Gibraltar arc, Geology, 17.6, 540-543.

Platt, J.P., Behr, W.M., Johanesen, K. \& Williams, J.R., 2013. The Betic-Rif Arc and its orogenic hinterland: a review, Ann. Rev. Earth planet. Sci., 313-357.

Romagny, A. et al., 2014. Late Miocene to Present-day exhumation and uplift of the Internal Zone of the Rif chain: insights from low temperature thermochronometry and basin analysis, J. Geodyn., 77, 39-55.

Rossetti, F., Theye, T., Lucci, F., Bouybaouene, M.L., Dini, A., Gerdes, A., Phillips, D. \& Cozzupoli, D., 2010. Timing and modes of granite magmatism in the core of the Alboran Domain, Rif chain, northern Morocco: implications for the Alpine evolution of the western Mediterranean, Tectonics, 29, doi:10.1029/2009TC002487.

Royden, L.H., 1993. Evolution of retreating subduction boundaries formed during continental collision, Tectonics, 12, 629-638.

Saleeby, J., Le Pourhiet, L., Saleeby, Z. \& Gurnis, M., 2012. Epeirogenic transients related to mantle lithosphere removal in the Southern Sierra Nevada Region, California, Part I: implications of thermomechanical modeling, Geosphere, 8, 1286-1309. 
Sánchez-Rodríguez, L. \& Gebauer, D., 2000. Mesozoic formation of pyroxenites and gabbros in the Ronda area (southern Spain), followed by Early Miocene subduction metamorphism and emplacement into the middle crust: U-Pb sensitive high-resolution ion microprobe dating of zircon, Tectonophysics, 316(1), 19-44.

Seber, D., Barazangi, M., Ibenbrahim, A. \& Demnati, A., 1996. Geophysical evidence for lithospheric delamination beneath the Alboran Sea and RifBetic mountains, Nature, 379, 785-790.

Spakman, W. \& Wortel, R., 2004. A tomographic view on Western Mediterranean Geodynamics, in The TRANSMED Atlas: the Mediterranean region from Crust to Mantle, pp. 31-52, eds Cavazza, W., Roure, F., Spakman, W.W., Stampfli, G.M. \& Ziegler, P.A., Springer-Verlag, 2004.

Thurner, S., Palomeras, I., Levander, A., Carbonell, R. \& Lee, C.T., 2014. Ongoing lithospheric removal in the western Mediterranean: evidence from Ps receiver functions and thermobarometry of Neogene basalts (PICASSO project), Geochem. Geophys. Geosyst., 15(4), 1113-1127.

Timoulali, Y., Djellit, H., Hahou, Y., Jabour, N. \& Merrouch, R., 2013. New evidence of delamination in the Western Alboran Sea. Geodynamic evolution of the Alboran domain and its margins, J. Geodyn., 77, 206-216.

Valera, J.L., Negredo, A.M. \& Villaseñor, A., 2009. Asymmetric delamination and convective removal numerical modeling: comparison with evolutionary models for the Alboran Sea region, in Earth Sciences and Mathematics, Vol. II, pp. 1683-1706, eds Camacho, A.G., Díaz, J.I. \& Fernändez, J., Birkhäuser Basel.

Valera, J.L., Negredo, A.M. \& Jiménez-Munt, I., 2011. Deep and nearsurface consequences of root removal by asymmetric continental delamination, Tectonophysics, 502(1-2), 257-265.

Verges, J. \& Fernandez, M., 2012. Tethys-Atlantic interaction along the Iberia-Africa plate boundary: the Betic-Rif orogenic system, Tectonophysics, 579, 144-172.

Vernant, P., Fadil, A., Mourabit, T., Ouazar, D., Koulali, A., Martin Davila, J., Garate, J., McClusky, S. \& Reilinger, R., 2010. Geodetic constraints on active tectonics of the Western Mediterranean: implications for the kinematics and dynamics of the Nubia-Eurasia plate boundary zone, $J$. Geodyn., 49, 123-129.

Wessel, P., Smith, W.H.F., Scharroo, R., Luis, J.F. \& Wobbe, F., 2013. Generic mapping tools: improved version released, EOS, Trans. Am. geophys. Un., 94, 409-410.

Yamato, P., Burov, E., Agard, P., Le Pourhiet, L. \& Jolivet, L., 2008. HP-UHP exhumation during slow continental subduction: self-consistent thermodynamically and thermomechanically coupled model with application to the Western Alps, Earth planet. Sci. Lett., 271(1), 63-74. 